\title{
36. Suat Derviş külliyatına katkı: Ne Bir Ses Ne Bir Nefes
}

Seval ŞAHIN ${ }^{1}$

Tolga KARAHAN ${ }^{2}$

APA: Şahin, S.; Karahan, T. (2021). Suat Derviş külliyatına katkı: Ne Bir Ses Ne Bir Nefes. RumeliDE Dil ve Edebiyat Araştırmaları Dergisi, (24), 647-660. DOI: 10.29000/rumelide.995399.

$\ddot{\mathbf{O} z}$

Suat Derviş’in ilk romanlarından Ne Bir Ses Ne Bir Nefes (1923), yazarın sonraki yıllarda yazdıklarında da görülecek korku ve gerilim unsurlarının yoğun olduğu bir eserdir. Roman, ikinci evliliğini kendisinden çok genç bir kadınla yapan Osman, oğlu Kemal ve Zeliha arasındaki gerilimli ilişkiyi anlatır. Eserde bir babanın, karısı ve oğlu arasında yasak bir ilişki olduğundan ve oğlunun kendisini öldüreceğinden şüphelenmesi yüzünden sık sık kabuslar görmesi ve sinir buhranları geçirmesi sebebiyle tekinsiz bir atmosfer vardır. Osman'ın düşünceleri, arkadaşı İrfan Behçet'le yazı odasında yaptığı sohbetlerde ve meşin kaplı defterde yazdıklarında gizlidir. Eserin sonunda cinnet geçiren kahramanın sebep olduğu cinayet de bu defterde yazılanlarla ilişkilidir. Romanla aynı adı taşıyan ancak ne zaman yazıldığı belli olmayan üç sahnelik kısa bir oyun Muhsin Ertuğrul Arşivinde yer almaktadır ve şimdiye kadar bu oyundan Suat Derviş ile ilgili kaynaklarda bahsedilmemiştir. Küçük bir deftere Arap harfleriyle ve el yazısıyla kaydedilmiş bu oyunun yazıldığı tarihe dair defterde herhangi bir bilgiye yer verilmemiştir. Bu makalede, Muhsin Ertuğrul Arşivinde bulunan söz konusu oyun, bir romanı oyunlaştırma tecrübesinde yazarın pratiğini göstermek açısından ve yazarın külliyatına bir katkıda bulunmak amacıyla Arap harflerinden Latin harflerine aktarılmıştır.

Anahtar kelimeler: Suat Derviş, roman, oyun, Ne Bir Ses Ne Bir Nefes

\section{A new contribution to Suat Derviş literature: Ne Bir Ses Ne Bir Nefes}

\begin{abstract}
Ne Bir Ses Ne Bir Nefes (1923), one of the first works written by Suat Derviş, is a book in which the author intensively uses the elements of fear and tension that will be seen in the works she wrote in the following years. The novel tells the tense relationship between Osman, who made his second marriage to a woman much younger than himself, his son Kemal, and Osman's young wife Zeliha. Osman has nightmares almost every night and thinks that he will be killed by his wife and son, whom he thinks have a forbidden relationship. There is an uncanny atmosphere in the novel because of the father, who often suffers from nervous breakdowns. Osman's thoughts are hidden in the conversations he had with his friend İrfan Behçet in the writing room and also in the notes he wrote in his personal notebook covered with leather. The murder caused by the hero who went insane at the end of the novel is also related to what is written in this notebook. A three-scene short play, which has the same name as the novel but whose date is unknown, is in the Muhsin Ertuğrul Archive. This play of Suat Derviş has not been mentioned in any work done so far. There is no information in this
\end{abstract}

1 Prof. Dr., Mimar Sinan Güzel Sanatlar Üniversitesi, Fen-Edebiyat Fakültesi, Türk Dili ve Edebiyatı (İstanbul, Türkiye), sevals@gmail.com, ORCID ID: 0000-0003-1548-6763 [Araştırma makalesi, Makale kayıt tarihi: 06.06.2021-kabul tarihi: 20.09.2021; DOI: 10.29000/rumelide.995399]

Yüksek Lisans, Mimar Sinan Güzel Sanatlar Üniversitesi, Sosyal Bilimler Enstitüsü (İstanbul, Türkiye), tkarahan96@gmail.com, ORCID ID: 0000-0002-7247-8674

Adres | Address

RumeliDE Dil ve Edebiyat Araştırmaları Dergisi Osmanağa Mahallesi, Mürver Çiçeği Sokak, No:14/8 Kadıköy - ISTANBUL / TÜRKIYE 34714 e-posta: editor@rumelide.com tel: +90 $5057958124,+902167730616$

RumeliDE Journal of Language and Literature Studies Osmanağa Mahallesi, Mürver Çiçeği Sokak, No:14/8

Kadıköy - ISTANBUL / TURKEY 34714

e-mail: editor@rumelide.com,

phone: +90 5057958124 , +90 2167730616 
small notebook about the date of this Turkish play written in Arabic letters, which is handwritten. In this article, this play which is in the Muhsin Ertuğrul Archive, has been transferred from Arabic letters to Latin letters. Through this article, it is aimed to show the gamification experience of a novel, to show Derviş's writing practice and to make a contribution to Derviş literature.

Keywords: Suat Derviş, novel, play, Ne Bir Ses Ne Bir Nefes

\title{
Giriş
}

Cumhuriyet Dönemi edebiyatçllarından Suat Derviş çok sayıda eser kaleme almış, eserleri bugün külliyat halinde yayımlanan önemli bir yazardır. Serdar Soydan'ın araştırmaları sonucu Suat Derviş’in bugün, tefrika ve telif eserlerinin çoğu tespit edilmiş̧ir ve yayımlanmaktadır. (Soydan 2021) Bu da Suat Derviş edebiyatı ve onun 1930'lardan itibaren Türkiye'deki edebi kamuda ve edebiyat tarihindeki yerini düşünmemiz ve ona dair farklı sorular ortaya atmamız için yeni imkânlar sunmaktadır.

Suat Derviş, edebiyatımızda toplumcu gerçekçilikle öne çıkmış, yarattığı karakterlerle toplumdaki sınıf farklılıklarını, toplumun yoksul ve ötelenmiş kesimlerini anlatan romanlar ve hikâyeler yazmıştır. Eserlerinde iktidarın kurduğu baskının bireyler arasında yarattığı eşitsizlik kadar kadınların özgürleşmesi de önemli bir yer tutar. İlk dönem eserlerinde genç kadınların kendilerinden yaşça büyük erkeklere duyduğu ilgiyi işleyen Suat Derviş, bunlarda korku ve gerilimi de ön planda tutar ve gotik unsurlara bol miktarda yer verir. Sonraki süreçlerde edebiyattaki bu tutumunu tamamıla toplumcu gerçekçi bir çizgiye taşıyacaktır. Onu edebiyat tarihimiz açısından farklı kılan bir diğer unsur, 1930'lu yıllardan itibaren çok dilli bir yazar olarak dünya edebiyatı sahnesinde yer almasıdır:

\begin{abstract}
“1930-32 arasında yazar olarak Almanya'da çalışmıştım. 1953’te Avrupa'ya gittim. Fransa'da iki kitap çıarttım, birini Türkçe yazdım, kız kardeşim Fransızcaya tercüme etti, (Ankara Mahpusu) ikincisini ben doğrudan doğruya Fransızca yazdım, o gözden geçirdi. (Yalının Gölgeleri) Paris’te Les Lettres Française, İstanbul'da ilk defa Tan gazetesinde çıkmış olan ve sonra birkaç kere haftalık dergilerde ve bayram gazetelerinde çıkan 'Fukara Ölüsü' isimli uzun bir hikâyem intişar etti. Horizon'da, Les Femmes D'aujourd'hi, Les Femmes Française, Eve, Antoinette dergilerinde, Parisien Libere gazetesinde çıan hikâye ve romanlarım vardır. İki Almanya'da, Çekoslovakya'da, Polonya'da, Sirbistan'da, Hindistan'da, Finlandiya'da, Romanya'da, Kanada'da, İngiltere'de, Japonya'da, İspanya'da, İskandinavya'da, Kızıl Çin'de hikâyelerim tercüme edildi. Batı Almanya'da Kölnischer Anzeiger, Morgenpost, Bild ve daha birçok yevmi gazetelere makaleler verdim. Avusturya'da Volksstimme gazetesine devamlı olarak hikâyeler verdim ve Stimme der Frau kadın gazetesinde Yalının Gölgeleri romanım çıktı.” (1976, 609)
\end{abstract}

Suat Derviş hakkındaki kaynaklara baktığımızda, uzun yıllar çok sayıda eser yazmış, röportajlar yapmış, makaleler kaleme almış yazarın, gördüğümüz kadarıyla roman, hikâye, makale, anı, röportaj dışında yazdığı türler arasında tiyatrodan bahsedilmemektedir. 3 Bu makalede konu edineceğimiz Ne Bir Ne Bir Nefes oyunu, onun şimdilik yazdığı tek oyundur.

Edebiyatçıların külliyatlarının tamamlanması, edebiyat tarihinde ve eleştirisinde yeni sorular sormak ve o edebiyatın gelişimini farklı açılardan sorunsallaştırabilmek için önemlidir. Bu makalede, edebiyat tarihi çalışmalarına ve Suat Derviş külliyatına katkıda bulunabilmek için Suat Derviş ile ilgili

M. Niyazi Acun'a verdiği röportajda şöyle demektedir: "Bir tane de Yapışkan ismiyle bir piyes yazdım. Darülbedayi'de oynand. Bunu Darülbedayi'ye verirken yalan söyledim. Almancadan tercümedir, dedim. (Gülerek) Bugün, bunu itiraf edecek yaşa geldim." Zihni Turgay Anadol ile yaptı̆̆ konuşmada ise şöyle der: "Piyes yazarlarımız arasında ilk piyesini yazmış olduğum bile vardır zannediyorum.

Kendisi daha iyi bilir.

'Kimdir bu?'

'İsmini unuttum. Benden imzamla oynatamayacağım bir piyesi ücret mukabilinde satın alan ve o sıralarda bana çok büyük maddî bir yardımda bulunmuş olan pek iyi bir dosttu herhalde. Ama ismini unuttum.'”

Adres | Address

RumeliDE Dil ve Edebiyat Araştırmaları Dergisi $\quad$ RumeliDE Journal of Language and Literature Studies Osmanağa Mahallesi, Mürver Çiçeği Sokak, No:14/8 $\quad$ Osmanağa Mahallesi, Mürver Çiçeği Sokak, No:14/8

Kadıköy - ISTANBUL / TÜRKIYE 34714 Kadıköy - ISTANBUL / TURKEY 34714 e-posta: editor@rumelide.com e-mail: editor@rumelide.com, tel: +90 505 7958124, +90 2167730616 phone: +90 505 7958124, +90 2167730616 
çalışmalarda yer verilmemiş Ne Bir Ses Ne Bir Nefes adlı romanından yola çıkarak yazdığı ve aynı adı taşıyan oyunundan bahsedilecektir. Makalede önce oyuna kaynaklık eden Ne Bir Ses Ne Bir Nefes romanından söz edilecek, ardından oyuna geçilecektir.

\section{Ne Bir Ses Ne Bir Nefes Romanı}

Ne Bir Ses Ne Bir Nefes Suat Derviş’in ilk eseri Kara Kitap romanında olduğu gibi korku, gerilim unsurlarının yoğun olduğu bir eserdir. Eser, 1923 yllında Orhaniye Matbaası tarafından yayımlanır. Yayımlandığı yıllarda pek dikkat çekmeyen roman, Ahmet Haşim’in 22 Şubat 1923’te Akşam gazetesinde neşrettiği "Bir Genç Kızın Eseri” adlı yazıyla odak noktası haline gelir. Haşim, romanı Maeterlinck, Edgar Allan Poe, Fransız Adam, Emerson gibi yazarların eserleriyle karşılaştırarak onu korku edebiyatının bir türü olarak anlatır.

Roman, ikinci evliliğini kendisinden çok genç bir kadınla yapan bir baba, Osman, yirmi beş yaşından sonra babasına kavuşan oğul, Kemal ve bu genç eş, Zeliha arasındaki gerilimli bir ilişkiyi anlatmaktadır. Evin babası Osman son derece şüpheci, çok geç kavuştuğu oğluyla ilgili sanrılar gören biridir. Yer yer ketum bir karakter olarak da tanımlayabileceğimiz Osman, arkadaşı İrfan Behçet'le yazı odasında yaptığı sohbetlerde, hayata, aşka ve kuşkularına dair düşüncelerini açığa çıkarır. Kendini yaşlanmış ve çirkin bulan Osman'ın oğlu ve genç karısı arasında bir ilişki olabileceğine dair sanrıları giderek tehlikeli bir durum alır ve Zeliha'yı korkutmaya başlar. Eşine duyduğu sevgiden emin olan adam, onun tarafından yeterince sevilmediğini düşünmektedir. İlk evliliğinden olan oğlu Kemal ise babasıyla geç kavuşmanın verdiği hissizlikle ondan son derece uzaktır. Babadan çok yaşça büyük bir birey gibi gördüğ̈̈ Osman'ın zaman zaman kendini kaybetmesine ve kötü rüyalar görmesine yine onun varlığı sebep olur. Eşini mutlu etmeye çalışan Zeliha, Osman'ın hastalığının-mutsuzluğunun yegâne sebebi olarak kendisini görür. Osman'ın yazı odasında bulunan ve yanından pek ayırmadığı defter Zeliha'nın sürekli ilgisini çekmektedir. Eşinin geçirmiş olduğu sinir krizlerinin sebebinin bu defterde saklı olduğunu düşünen Zeliha, açmaya tereddüt ettiği meşin kaplı defterin satırlarını okuduktan sonra dehşete düşer: Osman'ın tüm sanrıları oraya kaydedilmiştir. Osman'ın sürekli gördüğü kâbusların ve kuruntularının sebebinin açık bir şekilde okunduğu asabi satırlar, ailenin yaşayacağı feci sonu bildirmekle kalmayıp olayların farklı bir boyut kazanmasına da sebebiyet verir. Zeliha, kocasının ruh halindeki değişimlerin ve sahip olduğu kuruntuların tek sebebinin üvey oğlu Kemal ve onunla alakalı bir rüya olduğunu anlar. Osman'ın sık sık kâbuslarında gördüğü, kendi cenazesini omuzunda taşıdığını ifade ettiği ve karısına âşık olan esmer erkeğin Kemal'den başkası olmadığına ikna olur. Böylece eserde kendini yoğun olarak gösteren kıskançlı̆̆ın asıl sebebi ortaya çıar ve olaylar, bir gece vakti cinnet geçiren babanın öz oğlunu kendisine hediye ettiği hançerle öldürmesiyle son bulur.

Roman, tek bir mekânda ve dört kişi arasında geçmektedir. Bunlardan Osman'ın arkadaşı İrfan, romanın başında bir konuşma sahnesinde görülür, geri kalan kısımlarda Zeliha, Osman ve Kemal vardır. Diyaloglara iç konuşmaların da eşlik ettiği romanda, Osman'ın defteri ve rüyalar romandaki gerilim unsurunu artırır. Kemal'in gizemli tavırları ve zaman zaman yaptığı anlaşılmaz konuşmalar evdeki tekinsizliği besler. Hem Kemal hem Osman’ın yaptıkları Zeliha’yı korkutur. Böylece roman bu üç karakter arasında giderek ivme kazanan bir gerilim ortamıyla kısa bir zaman diliminde yaşananların korkunç bir sonla bitmesini anlatır.

\footnotetext{
Adres | Address

\begin{tabular}{r|l} 
Adres & Address \\
RumeliDE Dil ve Edebiyat Araştırmaları Dergisi & RumeliDE Journal of Language and Literature Studies
\end{tabular} Osmanağa Mahallesi, Mürver Çiçeği Sokak, No:14/8 $\quad$ Osmanağa Mahallesi, Mürver Çiçeği Sokak, No:14/8 Kadıköy - ÍSTANBUL / TÜRKIYE 34714 Kadıköy - ISTANBUL / TURKEY 34714 e-posta: editor@rumelide.com e-mail: editor@rumelide.com, tel: +90 505 7958124, +90 2167730616 phone: +90 505 7958124, +90 2167730616
} 


\section{Ne Bir Ses Ne Bir Nefes Oyunu}

Romanla aynı adı taşıyan ancak ne zaman yazıldığı belli olmayan üç sahnelik kısa bir oyun da Muhsin Ertuğrul Arşivinde yer almaktadır.4 Küçük bir deftere Arap harfleriyle ve el yazısıyla kaydedilmiş bu oyunun yazıldığı tarihe dair defterde herhangi bir bilgiye yer verilmemiştir. Oyundaki kurgu ile romandaki kurgu açısından hiçbir farklılık yoktur. Aynı şekilde romanda yer alan dört şahıs oyunda da vardır. Bu oyun, Suat Derviş edebiyatında türler arasındaki farklılıkları görmek, yazarın aynı eseri farklı türlerde yazma tecrübesini görmek açısından önem taşımaktadır ve yazarın külliyatına bir katkıda bulunmak amacıyla Arap harflerinden Latin harflerine aktarılmıştır.

Eşhas

Zeliha: Osman'ın karısı. Kemal'in üvey annesi.

Osman

Kemal

İrfan: Osman'in dostu.

Birinci Meclis Sahne

“Osman'in yazı odası.”

Birinci Meclis

Osman. Zeliha. Kemal. İrfan.

(Perde açılmadan piyano çalar. Perde açıldı̆̆ı zaman piyano susmuştur.

İrfan- Öyle güzel çalıyorsunuz ki Zeliha Hanım.

Zeliha- Öyle mi İrfan Bey?

İrfan- Eğer dünyada ilahi bir şeyin olduğuna inanabilseydim bu ilahi şey sizin parmaklarınızdır.

Zeliha- Ne kadar naziksiniz İrfan Bey.

İran- Bilemem ben nazik miyim? Fakat herhalde siz musikide bir harikasınız. (Osman'a döner.) Ben dünyada hiçbir şeyin mevcudiyetine hatta kendi varlığıma bile inanmam. Sizin evinizdeki saadete iman etmemek elden gelmiyor.

Zeliha- Öyle mi zannediyorsunuz İrfan Bey? Çok yanılıyorsunuz. Bana öyle geliyor ki ben Osman’ı mesut edemiyorum.

İrfan- (Osman'a) Öyle mi Osman? (Zeliha'ya döner) İnanamam. Osman ki dünyada her şeye inanır. Hatta ruha bile. Nasıl oluyor da sizin bir saadet olduğunuza iman etmiyor. Bu bir hakikattir Zeliha Hanim.

Zeliha- "Acı acı güler." Kabahat bendedir besbelli. Ben onu mesut etmesini bilmiyorum.

Osman- (Zeliha’nın saçlarını çeker gibi okşayarak) Ne için böyle hainsin Zeliha?

Zeliha- Ben mi hainim Osman? (Gözlerinin içine bakarak yerinden kalkar.) Bak bana doğru söyle. Sen mesut musun? (Osman Zeliha'nın ellerini tutar, okşar.)

Osman- Senin hayatında nâkâbil temel(li) bir yük olduğumu biliyorum. Ve kendi kendime soruyorum ki acaba seninle evlenerek sana büyük fenalık mı yaptım?

Zeliha- Osman!

Osman- İşte bunun için muazzebim. İşte bunun için böyle asabi hırçın oluyorum. Ben hemen hemen bir ihtiyarım. Sen genç ve güzelsin. (İrfan'a döner.) Görüyorsun ya İrfan ne saçmalar söylüyorum. İhtiyarladıkça gülünç oluyorum. Pek gülünç bir ihtiyarım değil mi?

İrfan- Hayır Osman. Sen bir insansın o kadar. (Osman’ın omuzlarını okşar.)

Osman- Nereye gidiyorsun Zeliha?

Bizi bu oyundan haberdar eden Serdar Soydan'a çok teşekkür ederiz.

Adres

RumeliDE Dil ve Edebiyat Araştırmaları Dergisi Osmanağa Mahallesi, Mürver Çiçeği Sokak, No:14/8 Kadıköy - ISTANBUL / TÜRKIYE 34714 e-posta: editor@rumelide.com

RumeliDE Journal of Language and Literature Studies Osmanağa Mahallesi, Mürver Çiçeği Sokak, No:14/8

Kadıköy - ISTANBUL / TURKEY 34714 tel: +90 $5057958124,+902167730616$

e-mail: editor@rumelide.com,

phone: +90 5057958124, +90 216773 o 616 
Zeliha- Sizin konuştuğunuz lisan bana çok yabancı. Her cümlesi kulaklarımı değil ruhumu yoruyor. Öyle yoruldum ki yine. Gergefime gidiyorum... Dinlenmek için... Sen beni uzaktan seyretmeyi seversin değil mi?

Osman- Bazen evet.

(Zeliha gergefin önüne oturur. Sahnede bir müddet sükût.

Osman'la İrfan'ın arasında bir (...)5 geçer.

(Zeliha mükâlemeyi dinlemeye uğraşır.)

Osman- Evet İrfan işte böylece hepsini biliyorum.

İrfan- Ben de sana sen, hastasın Osman diyorum. Sen kocaman bir hastasın.

Osman- Niçin bana hasta diyorsun da kendinizin, evet hepinizin eksik insanlar olduğunuza inanmıyorsun? Sizler bir șey tahattur etmediğiniz için bu şeylerin olmadığına iman edeceğime, kendi bildiklerime, hatırladıklarıma inanmak daha doğru değil mi?

İrfan- (Güler.) Çocuk gibi konuşuyorsun. İnsan yalnız bir kere dünyaya gelir. Bütün söylediklerin, tevehhüm ettiklerin saçma ve manasız şeyler. Anlıyor musun? Saçma ve manasız şeyler... Dünyada fevkattabia hiçbir şey yoktur.

Osman-(Müteheyyiç ve asabi) Hâlbuki ben... Ben sana bunların imkânsız şeyler olmadı̆̆ını biliyorum diyorum. Artık bende hatıralar bulanık ve silik değil. Anlıyor musun? Ben şimdi her şeyi bütün vuzuhuyla dünkü bir vakayı tahattur eder gibi hatırlıyorum. (İrfan gülüyor...) Gülme İrfan.

Ben mustaribim. Öyle mustaribim ki... Korkuyorum. O odadayken, o yanımdayken, onunla konuşurken karşımda ötekini görüyorum zannediyorum. (Kemal'e bakar.) Ses o... Bakış o, çenesindeki kıvrım... Gözlerindeki mana, hepsi o... Zeliha'ya gelince onun her bir hareketini nazarımdan kaçırmamaya gayret ediyorum. Gözleri ona çevrilecek, karşımda eskisi gibi şirin mana ile bakışacaklarından korkuyorum, titriyorum. Biliyorum İrfan biliyorum siz eksik insanlarsınız. Siz anlamazsınız. Hâlbuki ben... Ben hissediyorum. Bu benim kaderim olacak. (Bir müddet susar.) Felaket geliyor. Bir felaket yaklaşıyor. Felaket yakındır insanlar (dünyaya) her gelişlerinde. Çünkü hayat bir tekerrürden ibarettir ve insanlar her gelişlerinde aynı şeyi yapmakla mükelleftirler, siz bunu bilmiyorsunuz.

İran- Zavallı Osman... Çok asabisin ve küçük bir çocuk gibi manasız şeyler söylüyorsun.

Osman- Belki haklısın İrfan... Kim bilir? Belki...

(İrfan'ın yakınından ayrılarak Zeliha'ya yaklaşır.)

Ne yapıyorsun Zeliha? Gergef işlemiyor musun? Bugün o da seni eğlendirmiyor? Sıkılıyor musun Zeliha...

Zeliha- Ben mi? Hayır Osman sıkılmıyorum.

Osman- Niçin yalan söylüyorsun? Niçin saklamak istiyorsun anlamıyorum. Niçin saklamak istiyorsun ben anlamiyor muyum?

Zeliha- Yanılıyorsun Osman.

Osman- Sahteliğe lüzum var mı küçük?

Zeliha- Öyle sağırsın ki.

Osman- Beni sevmediğini bilmiyor muyum? (Zeliha ellerini Osman’a uzatır.)

Zeliha- Neden bana inanmak istemiyorsun?

Osman- Beni sevmiyorsun. Beni sevmiyorsun küçük. (Omuzlarından tutup silkeleyerek) Seni seviyorum desene. Haydi, beni sevdiğini söylesene.

Zeliha- Bunu pek iyi biliyorsun.

Osman- Hayır, hayır sen söyle.

Zeliha- Osman neyin var? Biliyorsun ki seni severim. Niçin beni üzmekten zevk alıyorsun?

Osman- Beni sevmeni istiyorum.

Burası metinde karalanmış şekildedir.

RumeliDE Dil ve Edebiyat Araştırmaları Dergisi Osmanağa Mahallesi, Mürver Çiçeği Sokak, No:14/8 Kadıköy - ÍSTANBUL / TÜRKIYE 34714 e-posta: editor@rumelide.com tel: +90 $5057958124,+902167730616$
Address

RumeliDE Journal of Language and Literature Studies Osmanağa Mahallesi, Mürver Çiçeği Sokak, No:14/8

Kadıköy - ISTANBUL / TURKEY 34714

e-mail: editor@rumelide.com,

phone: +90 505 7958124, +90 2167730616 
Zeliha- Fakat seni seviyorum Osman.

(Sükût...)

Osman- Zeliha?

Zeliha- Efendim?

Osman- Niçin konuşmuyorsun?

Zeliha- Ben mi? Bilmem...

Osman- Ben biliyorum. Benden sıkılıyorsun. Ben yanında olduğum zaman susuyorsun. Benden başka herkesle konuşuyorsun.

Zeliha- Herkesle mi? Gitgide çocuk oluyorsun. Bizim evde kiminle konuşulur?

Osman-Benden başka herkesle. Hatta hizmetçilerle bile. Benden çok Kemal'e söyleyecek söz buluyorsun. (Kemal'i gösterir.)

Zeliha- Bu sözü daima söylüyorsun Osman. Kemal'e üvey annelik ettiğimi mi istiyorsun? Zaten onun annesinin mevkiini aldığım için kendimi ona karşı adeta kabahatli hissediyorum.

Osman- Ne çılgınlık!

İrfan- Artık baş başa konuştuğunuz elverir. Ben gidiyorum. Evet, geciktim bile... Allah'a ısmarladık Zeliha Hanım. Allah'a ısmarladık Kemal Bey. (Kemal döner. Dalgın dalgın başıyla selamlar.)

Osman- Dur, beni bekle. Kapının önüne kadar çıkaracağım. Serin bir havaya o kadar ihtiyacım var ki. Ben şimdi gelirim Zeliha. (Kemal'e döner). Ben hemen gelirim Kemal.

(İrfan'la Osman çıkarlar.)

\section{İkinci Meclis}

Zeliha. Kemal.

Kemal- (Zeliha'ya yaklaşır. Uzun uzun gergefe bakar.) Ne... Hem de bu ince ipeklerin üstünde gözlerinizi yormaya acımıyorsunuz. Ve bütün bu şeyleri tabii canınızın sıkıntısını dağıtmak için yapıyorsunuz. Evet, ben de hissediyorum. Babamın da hakkı var. Siz çok sıkılıyorsunuz Zeliha.

Zeliha- Babanız gibi siz de yanılıyorsunuz Kemal. Ben sıkılmıyorum.

Kemal- (Gergefe hep dikkatle bakarak) Elleriniz balmumundan yapılmış kadar soluk. Elleriniz sonbahar günlerinden ilham almış. Sarı, mükedder, işinizin üstünde, ne güzel görünüyorlar. Ne güzel bir iş işliyorsunuz. Bu acayip karışık işlerinizin içinde bulutların koyu kurşuni rengi, toprağa bir altın yağmuru gibi dökülen sarı yaprakların zenginliği var. Bu işte akşam karanlığı gibi loş olan sonbahar günlerinin hüznü ve sizin düz, muntazam çizgileriniz var. (Bu sözleri söylerken yavaş yavaş Zeliha'nın karşısına geçer alçak bir iskemleye oturur.) Zaten sizi ilk gördüğüm gün hiç... Hiç güneş görmediğinizi zannettim. Siz gölgede yetişmiş bir yaprak gibi renksiz ve incesiniz. O kadar incesiniz ki dokunulacak olsa sanki binlerce parça olarak yere döküleceksiniz. Bilmiyorum hangi memleketin masallarındaki sultanlara benziyorsunuz? Sizde her şey gayr-ı hakiki (Zeliha.)

(Zeliha cevap vermez. ) Siz bir şey söylemiyorsunuz.

Zeliha- Sizi dinliyordum Kemal, hem sonra elimdeki iş beni öyle meşgul ediyor ki...

Kemal- Biliyor musunuz ki çok güzelsiniz. Gergefinize eğilmiş başınızın ne düşünülmemiş çizgileri var. Sizi böyle gördükçe ressam olmak istiyorum.

Zeliha- (Dalgın) öyle mi?

Kemal- Gözleriniz ne siyah ne derin. Sonra bakışlarınız çekingen, adeta korkak. Buraya geldiğimden beri hep sizinle meşgulüm. Doğrusunu isterseniz burada sizin yerinizde büsbütün başka bir kadın göreceğimi zannetmiştim.

Zeliha- Bir üvey anne değil mi?

Kemal- Belki, babamı da büsbütün başka bir adam tahayyül ederdim. Fakat geldiğim zaman şaşırdım.

Zeliha- Neden?

Adres

RumeliDE Dil ve Edebiyat Araştırmaları Dergis Osmanağa Mahallesi, Mürver Çiçeği Sokak, No:14/8 Kadıköy - ISTANBUL / TÜRKIYE 34714 e-posta: editor@rumelide.com tel: +90 $5057958124,+902167730616$
Address

RumeliDE Journal of Language and Literature Studies Osmanağa Mahallesi, Mürver Çiçeği Sokak, No:14/8

Kadıköy - ISTANBUL / TURKEY 34714

e-mail: editor@rumelide.com,

phone: +90 5057958124, +90 2167730616 
Kemal- Babam hiç de düşündüğüm insana benzemiyor. Çok daha genç çok kuvvetli... Sonra sizin karşınızda şaşırıp kalmıyor, bununla beraber sizi uzaktan zannettiğimden pek daha fazla seviyor. Zaten başka türlü olamaz ki. Fakat babamın büyük bir haksızlı̆gl var. O genç, güzel bir erkeğin herhangi bir kadından bekleyeceği kuvvetli, şiddetli bir aşkı sizden istiyor. Nereye bakıyorsunuz Zeliha?

Zeliha- Ben bir yere bakmıyorum, sizi dinliyorum.

Kemal- Sizi sıkıyor muyum? Susayım mı?

Zeliha- Devam ediniz Kemal, beni alakadar ediyorsunuz.

Kemal- Öyleyse dinleyiniz. Size gelince diyordum. Size gelince siz yaşlı bir adamın çılgın aşkından büyük zaafından istifade etmeyi düşünen fettan bir kadın değilsiniz. Elinizden geldiği kadar... Şayan1 hayret bir sabır ve merhametle manasını, faydasını anlamadığı bu iki hisle onu memnun etmeye gayret ediyorsunuz. Fakat bütün arzunuza rağmen babam mesut olmuyor. Çünkü siz onu sevmiyorsunuz.

Zeliha- Ben babanızı çok seviyorum Kemal. Ben onu bir baba, bir kardeş bir dost gibi seviyorum. Ben onu bütün, bütün muhabbetlerle, bütün bu yakınlıklarla seviyorum.

Kemal- Fakat aşkla değil.

Zeliha- Niçin böyle düşünüyorsunuz?

Kemal- Ben düşünmüyorum yalnız. Görüyorum Zeliha.

Zeliha- Babanızı mesut edemediğim için bana serzeniş mi ediyorsunuz?

Kemal- Çocuk musunuz? (Bir müddet sükût) Ne düşünüyorsunuz Zeliha?

Zeliha- Hiç, işim beni öyle meşgul ediyor ki.

\section{Üçüncü Meclis}

Evvelkiler. Osman.

Osman- (Girerken) Dışarıda hava çok serin, başımın sızıları hemen hemen geçti.

Zeliha- Ben de işi işlemekten bunaldım, şimdi biraz da benimle çıkar mısın?

Osman- Nereye gitmek istiyorsun?

Zeliha- Bilmem.

Osman- Ben biraz yoruldum da hem okumak istiyordum.

Zeliha- Okumak için' ${ }^{6}$ bir sürü karlı, yağmurlu kış günleri var. Zaten ben kendi kendime soruyorum ki senin okumadığın kitap kaldı mı?

Osman- Biraz mübalağa etmekle beraber bunda haklısın. Hem bu merakla okuduğum kitaplar benim bildiğim kadar da bilmiyorlar. Ben onlardan daha fazla biliyorum.

Zeliha- (Güler) Söyle bakalım sen onlardan fazla ne biliyorsun?

Osman- Ne mi biliyorum? O kendine yaklaşan Zeliha'yı kollarından tutup göğsüne doğru çekti. Senin Zeliha olmadan evvel ne olduğunu ve Zeliha olarak ne yapacağını biliyorum. Zeliha'yı bırakır. Sonra kendimin eskiden kim olduğumu, şimdi bu defa da ne olacağımı biliyorum. Daha sonra Kemal'in... (Gitgide yüksek sesle söyleyerek), Kemal'in evvelden ne olduğunu ve şimdi ne yapacağını biliyorum. Eminim ki bizim, hepimizin, senin, onun, benim birer ruhumuz var. Ezelden beri bu ruh ömrü çok kısa olan insani vücutlarda dolaşıyor. Onun ölümü yok. O ebediyen bu serseri koşuşunda devam edecek. Girdiği her yöne taliini, felaket ve saadetini beraber götürecek. Ve insanlar dünyaya her yeni gelişlerinde evvel yaşadıkları hayatı tekrar yaşayacaklar.

Zeliha- Öyle ciddiyetle söylüyorsun ki.

Osman- Çünkü ben bunu biliyorum. Çünkü ben hatırlıyorum.

Zeliha- (Biraz endişeli fakat gülerek) Neyi hatırlıyorsun?

$6 \quad$ Orijinal metinde burada karalanmış iki kelime bulunmaktadır.

Adres | Address

RumeliDE Dil ve Edebiyat Araşturmaları Dergisi Osmanağa Mahallesi, Mürver Çiçeği Sokak, No:14/8 Kadıköy - ISTANBUL / TÜRKIYE 34714 e-posta: editor@rumelide.com

RumeliDE Journal of Language and Literature Studies Osmanağa Mahallesi, Mürver Çiçeği Sokak, No:14/8

Kadıköy - ISTANBUL / TURKEY 34714 tel: +90 $5057958124,+902167730616$

e-mail: editor@rumelide.com

phone: +90 $5057958124,+902167730616$ 
Osman- Dünyada birinci birinci defa olarak yaşamadığımı hatırlıyorum.

Zeliha- Bana masal mı söylüyorsun Osman?

Osman- (Zeliha’nın elinden tutar) Böyle bizim üçümüzün beraber oluşumuz, bu söylediğimiz sözler, seslerimiz... Bakışlarımız sende müphem de olsa birtakım hatıralar uyandırmıyor mu? Bir saniyecik bile olsa yine ta evvelden üçümüzün...

Kemal- Baba... Baba bugün adeta çocuksunuz.

Osman- Ben mi Kemal? (Zeliha’yı bırakıp ona yaklaşır.) Hayır, ben bugün çocuk değilim. (Gözlerinde çlgın bir bakış vardır.) Yaklaş bana. (Birbirlerine yaklaşırlar.) (Daha yaklaş der. Kemal’i kollarından çeker.) Şimdi gözlerimin ta içine bak. Yüzüme yakından bak. (Bir müddet bakışır.) Bu yüz sana hiçbir şey hatırlatmıyor mu? Bu yüz sende asırlar atlamış hatıralar uyandırmıyor mu?

Kemal- Hayır baba... Sizin çehreniz yirmi beş yaşıma geldikten sonra tanıdığım babamın çehresidir ve bu yüz bana yalnız annemin ölümünden sonra beni evinizin kapısında karşıladığınız günü hatırlatiyor.

Osman- Öyleyse bu yüzü muhakkak gelmesi mukadder olan o gün hatırlayacaksın. (Yüzünde, gözlerinde cinnet vardır.) O gün bu yüzü tanıyacaksın.

Zeliha- Osman... Osman ne var, niçin böyle bakıyorsun?

Osman- (Başını elleriyle tutarak) Benim... Benim bir şeyim yok. Zeliha şuraya, enseme... Şakaklarıma... Başımın arkasına tuhaf bir ağrı geldi fena... Fena bir ağrı... (Güler) Merak mı ettin? Merak edecek bir şey yok ki. Hiçbir bir şey yok. Niçin bana böyle korkak gözlerle bakıyorsun?

Zeliha- (Sualli bir sesle) Beni öyle korkuttun ki. (A $\breve{g l a r .) ~}$

(Bu sıra Kemal dışarıya çıkar.)

Osman- Çocuk... Çocuk bak bana haydi. Şimdi gezmeye gidecekler. Bak havaya ne güzel, ağlama Zeliha'cığım. Sil gözlerini. (Kemal’i arayarak) Kemal sen de gelmez misin?

Perde iner.

Perde kapanırken7 kenarından tutmuş bir adam gelir. Perde kapandıktan sonra okumaya başlar.

Siyahlı adam-Osman'ın karısı, Kemal'in üvey annesi Zeliha sedirin üzerinde ayaklarını toplamış oturuyor. Osman'ın ${ }^{8}$ odasına her kapandığ zaman' en mesut veya felaketli dakikalarında onu meşgul eden bir defteri vardır. Bu kahverengi meşinden kaplı, oymalı dev gibi, ejderha gibi büyük defter şimdi Zeliha'nın karşısında yazıhanenin üstünde bulunuyor. Zeliha ufak bir hareket yapsa, elini uzatsa onu alacak. Onun ketum yapraklarında gizli olan sırrı yahut bir sürü hiçi okuyacak, öğrenecek. Zeliha emindir ki kocasını ondan ayıran, hasta eden, mustarip eden dert, sır, sebep orada, Osman'ın karışık yazısıyla siyah mürekkep lekeleriyle dolu olan o sayfalardadır.

Zeliha'nın kınalı saçları bükülmüş, bir ince fildişi tarakla toplanmış, üstünde kabarık kollu ve yakası bir yelpaze gibi açılarak dik duran soluk mavi taftadan beli sıkı, etekleri bol bir elbise var. O böyle uzaktan en üstat ellerden çıkmış eski İtalyan tabaklarının üstündeki kadınlara benziyor.

(İçerden saat beşi çalar.)

Zeliha sedirin üzerinde ayağıyla ipek yastıkları dövüyor. Defter hep karşısında duruyor.

(Saat altıyı çalar.)

Altı.

Defter yerinde duruyor, Zeliha hareketsiz gözleri hep defterin oymalı kabında.

(Saat yediyi çalar.)

Yedi.

Zeliha kımıldandı. Kalktı. Masaya yaklaşıyor. Parmaklar defterin ilk sayfasında. Korkuyor.

Ufak bir tereddüt... Fakat... Defter açılıyor. Zeliha Osman'ın asabi, dağınık yazısıyla yazılmış satırları okuyor.

Orijinal metinde bu kelimeden sonra karalanmıs iki kelime vardır.

Orijinal metinde bu kelimeden sonra karalanmış iki kelime vardır.

Orijinal metinde bu kelimeden sonra karalanmış altı kelime vardır.

Adres $\mid$ Address

RumeliDE Dil ve Edebiyat Araştırmaları Dergisi Osmanağa Mahallesi, Mürver Çiçeği Sokak, No:14/8 Kadıköy - ISTANBUL / TÜRKIYE 34714 e-posta: editor@rumelide.com

RumeliDE Journal of Language and Literature Studies Osmanağa Mahallesi, Mürver Çiçeği Sokak, No:14/8

Kadıköy - ISTANBUL / TURKEY 34714 tel: +90 $5057958124,+902167730616$

e-mail: editor@rumelide.com

phone: +90 $5057958124,+902167730616$ 
Perde açlırken siyahlı adam yavaş yavaş çekilir.

\section{İkinci Sahne}

\section{Birinci Meclis'o}

Zeliha sonra Kemal.

(Sayfaları çevirirken Kemal yavaş yavaş içeriye girer. Zeliha farkına varmadan arkasına gelir. Durur ve beraber okurlar. )

Hâlâ nüfuzunun taht-ı tesirindeyim. Ne karanlık ne hasta bir rüya idi. Bu beni rahatsız eden ilk kâbus değildi. Çocukluğumda bile korkarak, ağlayarak uyandiğım pek çok defalar vaki olurdu. Fakat bilmem niçin bu geceki kâbus beni bu kadar müteheyyiç ve hasta etti. Karanlk bir oda görüyorum. Bu odada bir adam yatağıma uzanmış yatıyordu. Bu adam kimdi? Bilmiyorum belki de bendim. Çünkü ben ayrıca odada olmadiğım halde kapıdan esmer, genç ve güzel bir adamın girdiğini görüyordum. Esmer adam yatağa yaklaş̧ıkça içimde duyduğum korkuya bakıllrsa yataktaki adam muhakkak bendim. Hâlbuki esmer adamın girdiğini ben gördüğüm halde yataktaki adam bilmiyordu. Ve genç adam bana yaklaştıkça ben meçhul bir mevcudiyete soruyorum. (Bu genç adam kimdir? Ne istiyor? ) Bana birisi cevap veriyordu. (Öldürmek istiyor.) (Kimi?) diye soruyordum. (Seni) diye cevap veriyorlard.. (Neden?) Yine meçhul ses mukabele ediyordu. (Çünkü o da senin karımı seviyordu.) Bana yaklaşan adamın elinde ince bir hançerin parladığım görüyordum. Bu hançer bana yaklaşıyordu. Fakat bir hareket yapamıyordum. Uyuyordum, korkuyordum. Genç adam eğiliyordu. Hançerin ucunu boğazıma bastırıyordu. Hançer boğazıma batarken bu acıyla gözümden her şey silindi. Yalnız sonsuz bir siyahlğın üstünde dev başı gibi iri başı vardı. Hançeri yavaş yavaş boğazıma sokan adamın, katilimin başı... Şimdi önümde ağır ağır giden bir cenaze alayı vardı. Benim cenaze alayım galiba. Lanet, içinde katilim vardı. Genç ve kuvvetli kolunu bir kadının beline dolamış, o kadınla yan yana gidiyorlardı. Bu kadın on altıncı asırda yaşayan kadınlar gibi giyinmişti. Saçları Venediklilerin ışıklı kırmızı saçlarının rengindeydi. Saçları o zamanki Floransalı güzeller gibi tanzim edilmiş fildişi taraklarla tutulmuştu. Ben bu kadın tanımak istiyordum. Fakat elindeki siyah bir örtü ile yüzünü örtmüştü. $B u$ arallk yine bir ses işittim. Yine o meçhul sesini bana o genç kadının beline sarllp tabutun arkasında yürüyen genci gösteriyordu. (Bak... Bak iyi tanı.) diyordu. Katilin... Katilin... Onu gör... Onu... Karınla beraber gidiyorlar. Ve kadının yüzünden örtü düşüyor. Bu karmızı saçl kadın benim Zeliha'mdı. Şimdi onlar birbirinden ayırmak istiyordum. Hareket edemiyordum. Çünkü ben bir ölüydüm. (Sayfalar çevirir tekrar okur.) İnanamadım. Gözlerimin hakikati gördüğüne inanamadım. Muhakkak bu tuhaf ve acayip bir tesadüften başka bir şey değildi. Kemali kucaklamak için açılan kollarım iki yanıma düştü. Çünkü ben bu başı bir yerde görmüştüm. Ben bu başı bir yerde tanımıştım. Kulağımda yırtıcı bir ahenkle öten korkunç bir ses vardı. Katilin... Katilin, onu gör. Onu tanı...

Evet, doğduğu günden beri bugüne kadar bir kere görmediğim oğlum rüyamda beni öldüren o güzel, esmer delikanlyyd. Evet, on altıncı asırda yaşamış kadınlar gibi süslenen, Zeliha'mun beline sarllp tabutumun arkasindan giden o delikanl...

Zeliha korkuyla defteri kapar, yerinden hızla aynaya yaklaşır. Kemal de teheyyüçtür. Zeliha'yı nazarlarıyla takip eder. On altıncı asırda yaşayan kadınlar gibi giyinmişim. Saçlarım Venedik kadınlarınınki gibi kırmızı ve ışıklı bir renge boyanmış saçlarım fildişi taraklarla tutturulmuş. (Tarağını eline alır, saçları dökülür.) Fildişi tarak. (O) Dökülen saçları elinde sıkar. Kırmızı ışıklı saçlar... Tekrar tarağa büyük bir dehşetle bakar. Fildişi tarak... Korku ile tarağı firlatır. Fakat elbisem... Kabarık kollu, bol etekli elbisem... On altıncı asıın ortasında yaşamış bir kadın gibiyim. Telaşla elbisesinin önünü çözüp çıkarmaya uğraşırken aynada kendine yaklaşan Kemal’i görür. Acı acı bağııır. (Ay.) (Arkasına döner, Kemal’i görür.) Kemal... Kemal siz burada... (Açllan elbisesinin göğsünü kapamaya uğraşır. Kemal ağır ağır Zeliha'ya yaklaşır. Omuzlarından tutar. Kendine doğru çeker. Ta yakından gözlerinin içine bakar.)

Kemal- Zeliha kırmızı ışıkıı saçlarınız... Ne güzel. (Saçlarını okşar.) Zeliha... Siz ne güzelsiniz.

Birden kapının perdesi sallanır. İçeride gürültüyle bir şey kırılır. Zeliha korkuyla yazıhanenin önüne kaçar.

Zeliha-Osman!

Orijinal metinde bu kelimenin ardından gelen yaklaşık bir paragraf tamamen karalanmıştır.

$$
\text { Adres | Address }
$$

RumeliDE Dil ve Edebiyat Araşturmaları Dergisi Osmanağa Mahallesi, Mürver Çiçeği Sokak, No:14/8 Kadıköy - İSTANBUL / TÜRKIYE 34714 e-posta: editor@rumelide.com

RumeliDE Journal of Language and Literature Studies Osmanağa Mahallesi, Mürver Çiçeği Sokak, No:14/8

Kadıköy - ISTANBUL / TURKEY 34714 tel: $+905057958124,+902167730616$

e-mail: editor@rumelide.com

phone: +90 $5057958124,+902167730616$ 
Kemal eliyle gözlerini kapayıp ${ }^{11}$ çıkar.

PERDE

Perde kapanırken siyahlı adam tekrar sahneye gelir.

Siyahlı adam- Osman'ın karısı- Kemal'in üvey annesi Zeliha.

Beyaz geceliğiyle pencerenin önündeki ipekli, yumuşak sedirinin üzerinde, elleri çenesinin altında, açık bir perdenin önünde beyaz bir mehtabın parlak ışı̆̆ılyla büsbütün beyaz görünen kırlara bakıyor. Sakin, soğuk bir gece... Etrafta ne bir hareket ne bir rüzgâr ne bir ses... Ne bir nefes var.

Karlar, lekesiz karlara uzanıp gidiyor. Bu gece her şey sakin ve yumuşak; her şey uyuyor.

Hayır, yanılmış olmalıyım. Her şey uyumuyor. Çünkü dışarıda, sofada çatırtılar var. Dışarıda biri mi geziyor... Zeliha nefes almaktan bile ürkerek etrafı dinlemeye başladı. Kalbi korkulu vuruşlarla saniyeleri sayıyor. Evet, dışarıda ayak sesleri var. Bazen yorgun, bazen hırçın, bazen metin, bazen cesaretsiz bir ahenkle döşemeleri döven ayak sesleri...

Zeliha yerinden fırladı. Şimdi ayakta beyaz geceliğinin etekleri ayaklarına dolaşırken kapıya koşuyor. Titrek parmakları anahtarı çeviriyor. Birkaç geceden beri onu korkutan bu şeyi görmek... O kadar korkuyor ki o şeyi gözleriyle görmezse dehşetinden ölecek.

Perde yavaş yavaş açılır.

\section{Üçüncü Sahne}

Zeliha sonra Osman.

Zeliha elinde şamdan, yüksek tutmuş; kapıdan dışarıya uzatmış bakar. Osman kapıdan girip Zeliha'nın arkasına gelir. Omuzlarını tutar.

Osman-Zeliha ne yapıyorsun?

Zeliha- Dışarıda bir gürültü duydum Osman, korktum. Ne olduğunu anlamak için...

Osman- (Sözünü keser.) Sen de duydun mu? Sen de duydun mu? Demek yanılmamışım. Kimi gördün?

Zeliha- (Tereddütle) Kimseyi görmedim. Aldanmış olmalıyım.

Osman- (Israrla) Kimseyi, hiç kimseyi görmedin mi Zeliha? Yalan söyleme, yalan söyleme.

Zeliha- Hayır kimseyi görmedim. (Osman şiddetle omuzlarını sıkar.) Osman canımı acıtıyorsun.

Osman- Demek kimseyi görmedin öyle mi? (Kahkahayla güler.)

Zeliha- Osman yemin ederim ki kimseyi görmedim.

Osman- Niçin yemin ediyorsun? Biliyorum ki yalan söylemiyorsun. Yalnız yalan söylenildiği zaman yemin edilir.

Zeliha- Üşüyorum. (Osman şamdanı Zeliha’nın elinden alır. Zeliha ısınmak ister gibi iki kolunu göğsünde kavuşturur. Osman kapıyı kapar. Anahtarı çevirir.) Osman öyle üşüyorum ki...

Osman- Titriyorsun. Gel... Gel... Henüz ateşi sönmemiş. (Şöminenin karşısına geçerler. Osman ateşi canlandırmaya uğraşır.)

Zeliha- (Isınarak) Çok üşüyorum.

Osman- Şimdiye kadar niçin uyumadın?

Zeliha- Uykum yoktu. Fakat sen de uyumamışsın.

Osman- (Güler.) Ben geceyi dinliyor ve seni bekliyordum.

Zeliha- Beni mi bekliyordun? Niçin?

Osman- Öyle ya insan bu sessiz gecelerin kollarında neler saklı olduğunu bilir mi? Belki bir tehlike, bir düşman kapımıza bilhassa kapına yaklaşır.

${ }_{11}$ Orijinal metinde bu kelimeden sonraki kelime karalanmıştır.

Adres | Address

RumeliDE Dil ve Edebiyat Araştırmaları Dergisi Osmanağa Mahallesi, Mürver Çiçeği Sokak, No:14/8 Kadıköy - İSTANBUL / TÜRKIYE 34714 e-posta: editor@rumelide.com

RumeliDE Journal of Language and Literature Studies Osmanağa Mahallesi, Mürver Çiçeği Sokak, No:14/8

Kadıköy - ISTANBUL / TURKEY 34714 tel: +90 $5057958124,+902167730616$

e-mail: editor@rumelide.com

phone: +90 5057958124 , +90 2167730616 
Zeliha- Yine bu gece gözlerinde o korkunç ışık var Osman. Bu ışığı gözlerinde görmemek için bütün hayatımı veririm. Böyle baktığın zaman öyle korkuyorum ki...

Osman- Mustaripsin değil mi Zeliha? Yanımda mustarip ve bedbahtsın değil mi? Beni sevmiyor, benden nefret ediyor; benden korkuyorsun değil mi?

Zeliha- Seni1 ${ }^{12}$ sevdiğimi biliyorsun Osman. Ben de beni sevdiğini, çok sevdiğini biliyorum. Sana minnettarım. Bilsen seni memnun etmeyi, seni mesut etmeyi ne kadar istiyorum. Sana karşı öyle müşfik bir dostluğum var ki fakat biliyorum çok beceriksizim. Belki çok genç, çok küçüğüm. Sen büyüksün. Seni nasıl ele almak, seni nasıl mesut etmek, seni nasıl temin etmek lazım geldiğini bilmiyorum. Ben bir şey bilmiyorum Osman. Kaşlarını çatma. Böyle fena gözlerle bakma. Ben senin zavallı... Zavallı, küçük, sersem Zeliha'nım. Senin küçücük, küçücügünüm. Seni mesut edemiyorsam kabahatli değilim. Bilsen bunun aksini ne çok istiyorum. Hayır, söylediğin gibi yanında bedbaht değil fakat mükedderim. Çünkü kabahat hep bende... Hep bende. Çünkü ben seni mesut edemiyorum. Bana dargın bakma. Gözlerin ne parlak... Ellerini bana ver Osman. Eminim atılmak... ${ }^{13}$ var. (Korkuyla ellerini çeker.) Elindeki nedir Osman? Onu elinden bırak.

Osman- Neden ben bu hançeri çok seviyorum. Bu bana Kemal'in bir hediyesi. Oymaları öyle güzel ki ucu biraz kördü ama.

Zeliha- (Endişe ile) Ucu biraz kördü ama ne oldu?

Osman- Bir şey olmadı. Onu bilettim. Hem insan yanında her zaman bir silah taşımalı hele bilhassa bunun gibi antika ve kıymetli olursa... İnsan başına ne geleceğini bilmez ki. (Bir müddet sükût) Bazen de bildiği halde kendini koruyamaz.

Zeliha- Ne dedin?

Osman- Hiç... (Lakırdıyı değiştirir.) Ne güzel bir hava... Ay ne kadar parlak.

Zeliha- Karlı gecelerin mehtabı çok güzeldir.

Osman- Her taraf rüyada görülen memleketler gibi beyaz ve temiz. Her taraf sükûn... Sükût içinde bütün gece... Ne bir ses ne bir nefes var.

Zeliha- Ne korkunç derecede güzel.

Osman- Böyle geceleri ne çok severim. (Dışarıda bir gürültü olur, döner.) Duymadın mı?

Zeliha- ( O da duyar, titrer.) Neydi?

Osman- Sofadaki ayak seslerini mi?

Zeliha- (Tereddütle) Hayır.

Osman- Yalan söylüyorsun.

Zeliha- Ben mi Osman?

Osman- Evet sen. Sen yalan söylüyorsun. Geziyordu, yine kapının önündeydi. Sen de duydun.

Zeliha- Neyi, kimi? Kim geziyordu?

Osman- Zeliha. Zeliha benimle oynama.

Zeliha- Ne söylüyorsun? Anlamiyorum.

Osman- Sen beni pek iyi anllyorsun fakat emin ol ki artık cesaretsiz ve korkak değilim. Artık kurban olmayacağım kadere, şeameti göstereceğim ki ben onlarla eğlenen, eğlenebilen bir adamım. Hükmetmek arzusu talileri, kaderleri, kâinatı değiştirir. Anlıyor musun küçük kadın? Sen benim karımsın. Senin sahibin, efendin benim. Beni seviyorsun, sade beni seveceksin. Seni öyle çok seviyorum ki sen de yalnız beni... Yalnız... Yalnız beni seveceksin. Çirkinim, korkuncum, ihtiyarım. Solgun sarı derim, düşük bıyıklarla örtülmüş bu ağzım; çekik gözlü bu başımla buna hakkım yoktur zannetme. Sen güzelsin. Fakat beni seviyorsun. Her şeye rağmen beni seviyorsun, beni seveceksin. Başka kimseyi değil. Anlıyor musun? Hayır anlayamazsın. Fakat sonra anlayacaksın. Sana bunu bilfiil gösterdiğim zaman anlayacaksın. Beni sevdiğini, beni sevmeye mecbur olduğunu anlayacaksın.

Zeliha- (Yalvaran bir sesle) Osman... Osman... Biraz sakin ol.

Orijinal metinde bu kelimenin önündeki kelime karalanmıştır. Buradaki kelime çok silik olduğu için okunamamıştır.

Adres

RumeliDE Dil ve Edebiyat Araştırmaları Dergisi Osmanağa Mahallesi, Mürver Çiçeği Sokak, No:14/8 Kadıköy - ISTANBUL / TÜRKIYE 34714 e-posta: editor@rumelide.com tel: +90 $5057958124,+902167730616$ 
Osman- Hayır, artık sakin olamam. Ben deliyim bak. Ben deliyim. (Zeliha korkuyla çekilir.) Şakaklarında uzun bir hayatın karlarını taşıyan başım hâlâ sütninelerin dizinde peri masallarını dinleyen bir çocuk muhayyilesi taşıyor. İrfan Behçet bunu bu sabah söylüyordu. Hakkı var mı bilmiyorum. Belki hepsi bir kâbus belki hepsi saçma. Belki hepsi cinnet ve delilik... (Kahkahalarla güler.) Kâbus... Kâbus küçük çocukları yaramazlıktan men etmek için uydurulmuş hurafe gibi esassız saçma bir şey öyle mi? Cevap versene Zeliha. (Geri geri çekildikçe arkasından gider.) Cevap versene niçin sustun? Sen de öyle düşünüyorsun değil mi?

Zeliha- (Yalvararak) Yeter Osman öyle korkuyorum ki.

Osman- Bana sen de hastasın Osman diyeceksin, hastasın. Hayır, Zeliha, hayır; hasta değilim. Deli değilim. Deli değilim. Mantığım bunların birini kabul etmiyor. Mantığım... Fakat oh... Dünyada mantıktan daha büyük, mantıktan daha saçma ne var? Ben mantıktan kuvvetli, mantıktan şiddetli şeylerin mevcudiyetini, büyüklügünü biliyorum. Ben mantı̆̆ı olmayan şeylerin kuvvetini, hakikatini biliyorum. Ben insanların mantığına gülüyorum. Ben dünyanın mantığına, ben mantığın mantığına gülüyorum. Hem de nasıl... (Kahkahalarla güler.)

Zeliha- (Ağlar bir sesle) Osman eğer beni seviyorsan eğer beni seversen başım için sus.

Osman- Seni seviyorum Zeliha. Seni seviyorum hem de nasıl. Öyle güzelsin ki, öyle kadınsın ki... Dikkat et çocuk yalan söyleme, yalan söylediğin zaman anlıyorum. Seni çok seviyorum. Onun için seni affetmem. (Birdenbire durur. Etrafinı dinler.) Duyuyorsun değil mi ayak seslerini, duyuyorsun değil mi? Demin de duydun değil mi?

Zeliha- (Ağlayarak) Duydum Osman duydum. Duyuyorum fakat artık bu bitsin korkuyorum. Korkuyorum artık bu bitsin yalvarırım.

Osman- Bitecek güzel. Yemin ederim ki bitecek. (Yerinden firlar. Hızlı hızlı yan kapıdan kendi odasına geçer.)

Zeliha- (Bağırır.) Osman! Osman! Korkuyla etrafına bakar. Yerinden kımıldamaz. İçeride büyük bir gürültüyle bir kapı açılır sonra kapanır. Acı bir feryat... Zeliha dizlerinin üstünde doğrulur. Bekler, sonra dizleriyle kollarıyla sürünerek kapıya doğru gitmeye uğraşır. İçeride hep gürültü devam eder. Bir şeyler kırılır. Sonra ağır bir cisim yere düşer. Bir hırıltı... Osman’ın sevinçli bir feryadı... Birkaç saniye sükût... Sonra Osman’ın odasının perdesi açılır. Osman içeri girer. Elinde hançer vardır. Zeliha'nın üzerine doğru yürüdükçe Zeliha korkuyla sedirin üstüne kaçar. Osman ona yaklaşır, tutar.

Osman- Artık hepsi bitti. Beni seviyorsun.

Perde.

\section{Sonuç}

Ne Bir Ses Ne Bir Nefes oyunu, Suat Derviş'in aynı adlı romanındaki kurguyla bire bir paralel ilerleyen, yazarın özellikle ilk dönem edebiyatını gözler önüne sermek açısından önemli bir eserdir. Roman, Zeliha'nın ağzından anlatılmıştır. Osman ve Kemal ile konuşmaları ve bu konuşmaların ardından onun zihninde uyananlara romanda bol miktarda yer verilir. Romanda Osman'ın defteri bir günlüktür, burada eski karısı Bihter ve onunla yaşadıkları dönem, Kemal ve karısı Zeliha ile ilgili düşünceleri anlatılır ancak oyundaki defterde sadece gördüğ̈̈ rüya vardır. Zeliha'nın defterdeki satırları okuduğu andan itibaren hem romanda hem de oyundaki tekinsizlik ortamı giderek etkisini artırır. Romanda, defter okunana kadar basit bir kıskançlı̆̆a ve ruhî bozukluğa ait olduğu zannedilen garipliklerin sonrasında varoluştan başlayarak kadın ve reenkarnasyona kadar birçok konuyla alakalı olduğu anlaşılır. Romanda Kemal'in satın aldığı hançer ve bunun üzerine yapılan konuşmalar, Osman'ın hançerle ilgili imaları oyunda yoktur. Kemal'in de Osman'ın defteri okuduğu ve babasının hasta olduğunu, onu tedavi ettirmeleri gerektiğine dair Zeliha ile yaptığı romandaki konuşma, oyunda yoktur. Zeliha'nın piyano çaldığı, Osman'ın bu çalış esnasında giderek asabileşmesi de oyunda yer almaz. Oyun da roman gibi kısadır. Suat Derviş'in genç yaşında (18) yazmış olduğu roman, onun en önemli eseri olmasa da ilerleyen yllarda yakalayacağı ve savunacağı kadın duyarlılığını müjdelemesi açısından dikkat çekicidir. Bu romandan uyarlanan oyunda tekinsiz atmosfer daha ön plana çıarılmış, romanda yer alan sahnelerin bir kısmı çıarılarak aynı sonla biten bir eser kaleme alınmıştır.

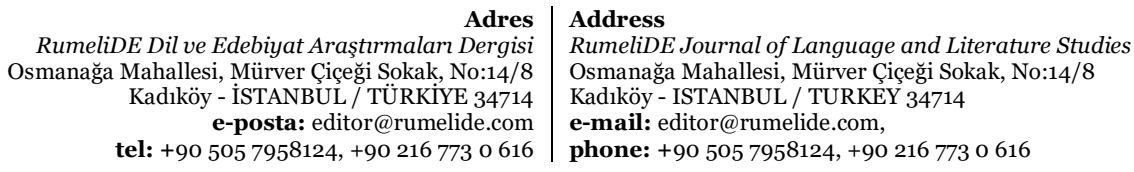




\section{Kaynakça}

Acun, M. Niyazi. Yedi yaşında romancı. Servet-i Fünun Uyanış, sayı: 2016/331. 11 Nisan 1935

Anadol, Z. T. Fransa'da yayımlanan ilk Türk romanı Ankara Mahpusu'nun yazarı Suat Derviş ile konuşma. Gerçekler Postası, sayı: 11-12, Ağustos-Eylül 1967.

Derviş, S. (1923) Ne Bir Ses Ne Bir Nefes. İstanbul: Orhaniye Matbaası

Derviş, S. (tarihsiz) Ne Bir Ses Ne Bir Nefes. İBB Atatürk Kitaplı̆̆ı Muhsin Ertuğrul Evrakı, nr: 11902.

Günay, Ç. (2001) Toplumcu gerçekçi Türk edebiyatında Suat Derviş̧in yeri. Bilkent Üniversitesi Sosyal Bilimler Enstitüsü Yayımlanmamış Yüksek Lisans Tezi.

Haşim, A. Bir genç kızın eseri. Akşam, 22 Şubat 1923, s. 8.

Necatigil, B. (1976) Dünya kadın yılında Suat Derviş üzerine notlar. Nesin Vakfi Edebiyat Yıllığı, s. 593609.

Soydan, S. (2021, Ocak 18) Suat Derviş’in bütün romanları.

http://sanatkritik.com/eski/kulliyat/suat-dervisin-butun-romanlari/

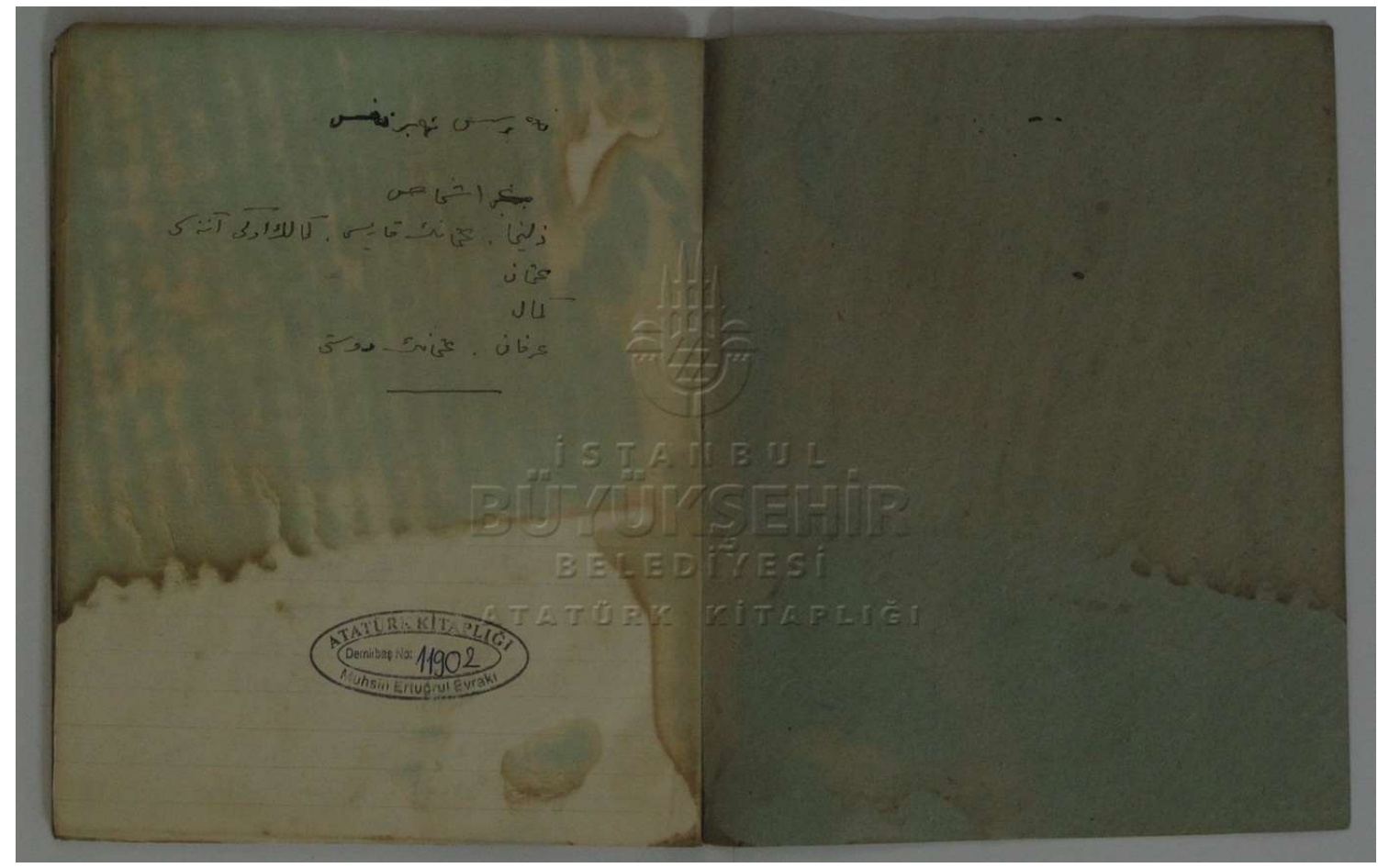

(Ne Bir Ses Ne Bir Nefes oyununun ilk sayfası)

RumeliDE Dil ve Edebiyat Araştırmaları Dergisi Osmană̆a Mahallesi, Mürver Çiçeği Sokak, No:14/8 Kadıköy - ISTANBUL / TÜRKIYE 34714 e-posta: editor@rumelide.com tel: +90 $5057958124,+902167730616$
Address

RumeliDE Journal of Language and Literature Studies

Osmanağa Mahallesi, Mürver Çiçeği Sokak, No:14/8

Kadıköy - ISTANBUL / TURKEY 34714

e-mail: editor@rumelide.com

phone: +90 $5057958124,+902167730616$ 
660 / RumeliDE Journal of Language and Literature Studies 2021.24 (September) A new contribution to Suat Derviş literature: Ne Bir Ses Ne Bir Nefes / S. Şahin; T. Karahan (pp. 647-660)

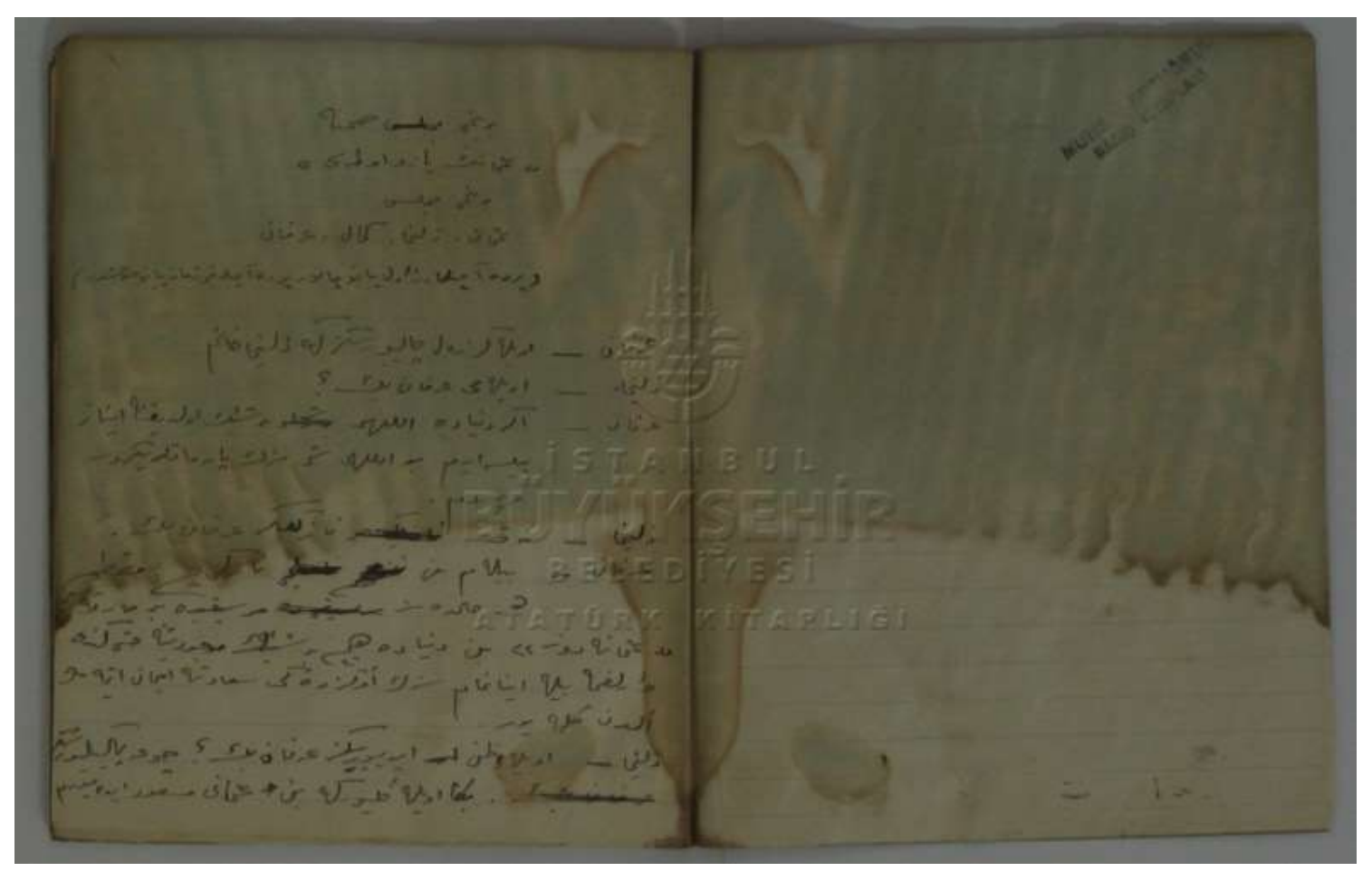

(Ne Bir Ses Ne Bir Nefes oyununun ikinci sayfası)

Adres | Address

RumeliDE Dil ve Edebiyat Araştırmalar Dergisi $\quad$ RumeliDE Journal of Language and Literature Studies Osmanağa Mahallesi, Mürver Çiçeği Sokak, No:14/8 Osmanağa Mahallesi, Mürver Çiçeği Sokak, No:14/8 Kadıköy - ISTANBUL / TÜRKIYE 34714 e-posta: editor@rumelide.com Kadıköy - ISTANBUL / TURKEY 34714

e-mail: editor@rumelide.com,

tel: +90 505 7958124, +90 2167730616 phone: +90 505 7958124, +90 2167730616 